\title{
What is the History of Anger a History of?
}

\author{
Thomas Dixon \\ Queen Mary University of London, UK \\ t.m.dixon@qmul.ac.uk
}

\begin{abstract}
This essay uses the history of emotions to make two arguments - one destructive and one constructive. It uses examples from intellectual and cultural history to undermine the idea that the modern English term 'anger' refers either to a clearly defined mental state or to a coherent emotional concept. At the same time, it also questions the diagnosis of the present as an 'age of anger'. Constructively, the essay uses the intellectual and cultural ancestries of modern 'anger' as a case-study in a distinctive approach to the history of emotions. With reference to works by linguists and anthropologists, to ancient philosophical and literary texts, and to some of the most influential visual representations of the irate body and the furious face, from Hieronymus Bosch to Charles Darwin, the essay explains and defends a pluralist and interdisciplinary approach, arguing that 'anger' is a modern English word without a stable transhistorical referent, and proposes the method of genealogical anatomy as a way to avoid the twin dangers of anachronism and essentialism in the history of emotions.
\end{abstract}

\section{Keywords}

anger - rage - ira - revenge - expression - historiography

\section{Introduction}

The question in the title of this essay seems, on the face of it, ridiculously easy to answer: 'anger' is the name of a human emotion, and the history of anger is the story of how that emotion has been experienced and expressed in the past. That might be the end of the matter if we agreed about what an 'emotion' was and about which 'emotions' were examples of 'anger'. Unfortunately, we do not. Ever since William James asked 'What is an emotion?' in 1884, psychologists 
have been engaged in divisive and inconclusive arguments about the correct answer. ${ }^{1}$ Further, as we shall see, there is no agreement about which aspects of reality the term 'anger' properly refers to. Candidates include the desire for revenge, hardwired homicidal instincts, moral indignation, bodily arousal, drunken brawling, and various kinds of facial grimacing. Which of these is an essential part of 'anger' and which, therefore, belong in a history of anger?

The first simple, largely destructive aim of this essay is to show how difficult it is to answer this question. It uses examples from Western cultural and intellectual history to explode the idea that any of us really knows what 'anger' means. The instability and inscrutability of reference of this modern emotional term is of fundamental importance and constitutes a challenge to anyone in any discipline seeking to make claims about a supposed entity called 'anger'. Such a crisis of definition is, of course, a problem encountered in almost any scholarly endeavour exploring complex concepts. However, the obviousness of the problem should not lead us to ignore it, nor to proceed as if the meanings of our key terms are clear and stable when they are not. For those who believe in anger as a universal 'basic emotion', the challenge will be to respond to the evidence marshalled below of radical discontinuity of experiences, ideas and expressions across time and cultures. For those of us, perhaps including many readers of this journal, who already accept that modern emotion words do not name natural kinds or human universals, we need to articulate what we think we are doing when we use those terms; to take greater care in explaining when we are, or are not, engaging in anachronism; and to articulate what, if anything, in human experience we think is shared across different emotional cultures. ${ }^{2}$

In a recent book about mental health, Nathan Filer seeks simultaneously to explore and to question the validity of one modern psychiatric category by referring throughout to 'so-called schizophrenia' rather than to 'schizophrenia." This acknowledges the power of the category, while keeping it at a distance, and I want to advocate something similar in the case of 'anger' and other emotion words. This is a contribution that the history of emotions can make, as a

1 William James, 'What is an Emotion?', Mind 9 (1884): 188-205; Thomas Dixon, “Emotion”: The History of a Keyword in Crisis', Emotion Review 4, no. 4 (October 2012): 338-44.

2 On the philosophical debate about whether either 'emotion' or specific emotion words such as 'anger,' 'fear' and so on name natural kinds, see Paul E. Griffiths, What Emotions Really Are: The Problem of Psychological Categories (Chicago: University of Chicago Press, 1997); Lisa Feldman Barrett, 'Are Emotions Natural Kinds?', Perspectives on Psychological Science 1 (2006): 28-58; Andrea Scarantino, 'How to Define Emotions Scientifically, Emotion Review 4 (2012): 358-68.

3 Nathan Filer, The Heartland: Finding and Losing Schizophrenia (London: Faber, 2019); a new edition of the book has the title This Book Will Change Your Mind about Mental Health: A Journey into the Heartland of Psychiatry. 
discipline, to a process of collective disenchantment, even of liberation. We all live under the spell of the psychological categories we inherit, and it is of service, in some cases, to try to loosen their hold over us. For that reason, in this essay, I do not refer to 'anger' in a way that suggests this English word has either an agreed definition or a coherent referent in the world, nor do I use singular phrases such as 'the emotion of anger', nor do I discuss what 'it' is or how 'it' has changed or been variously expressed over time. When it comes to 'anger', there is no 'it'. There is no discrete thing, entity or process in the world, past or present, to which the English word 'anger' invariably refers. It is surprisingly difficult, but important, to engage in a sustained discussion that remains grammatically true to this basic fact. ${ }^{4}$

The pioneering French historian of affectivity, Lucien Febvre, argued in 1938 that psychological anachronism was harmful and insidious, since each human group in the past in fact had its own proper mental system, working to produce experiences in its own way. ${ }^{5}$ This insight is crucial, and is only rarely acted upon in a consistent way, even among historians of emotions. However, on its own, a warning against psychological anachronism is not enough. It leaves us with a further challenge, namely to articulate how and why the experiences of past individuals relate to our ambiguous, if enchanting modern categories. If 'anger' and 'emotion' are, in one sense, only words - modern English-language constructs from which some of us wish to be liberated - then what are the phenomena that can be properly included in their histories? To put it another way: what are the criteria of inclusion in histories of time-bound modern emotions? Answering that question, and explaining how to produce historical work about the emotions that is rigorously true to their historicity without collapsing into relativistic nihilism about language and reality, constitutes the second, constructive aim of this essay, using modern so-called 'anger' as an example.

As I explain further below, my historical method combines anatomy with genealogy, and is simultaneously historicist and presentist. It is historicist because the ancestors I find for different aspects of modern emotional life are reconstructed in the terms of their proper historical contexts. It is presentist because the phenomena whose histories I seek to cobble together are those which at least some twenty-first century users of the term 'anger' have taken that word to refer to. Modern uses of 'anger' provide the anchor for the whole

4 In using the terms 'reference' and 'referent' I am alluding to philosophical debates about the ways that our words succeed or fail in trying to pick out aspects of reality; see A. W. Moore, ed., Meaning and Reference (Oxford: Oxford University Press, 1993).

5 Lucien Febvre, A New Kind of History: From the Writings of Febvre, ed. Peter Burke, trans. K. Folca (London: Routledge and Kegan Paul, 1973), 1-11. 
enterprise, even though the term has no stable referent. An awareness of our own historical moment and linguistic usage is, therefore, a crucial first step in beginning to answer our question: what is the history of anger a history of?

Since 2016 it has become a journalistic commonplace to say that we live in an age of anger. In June of that year, the British people voted by $5^{2}$ per cent to 48 per cent to leave the European Union, and 'anger' soon emerged as an explanation. A leading article in the Economist, entitled 'The Politics of Anger', suggested that 'anger' at immigration, globalisation, and social liberalism had stirred up the 'Leave' vote in the 'depressed, down-at-heel, cities of England'. ${ }^{6}$ Later that year, the election of Donald Trump as president of the United States was slotted into the same explanatory frame. During his campaign, Trump had said he was 'very, very angry' and would 'gladly accept the mantle of anger.'? On the morning after the result, the prominent Democrat politician Bernie Sanders issued a statement. 'Donald Trump', Sanders stated, 'tapped into the anger of a declining middle class that is sick and tired of establishment economics, establishment politics and the establishment media.' ${ }^{8}$ The Nobel Prize-winning economist Paul Krugman commented: 'It turns out that there is a deeper rage in white, rural America than I knew.' ${ }^{9}$ The political philosopher Judith Butler spoke of the 'vast anger' Trump voters felt, 'against migrants, against racial minorities, against Black Lives Matter, against women.. ${ }^{10}$

Donald Trump's election came in spite of repeated allegations of sexual misconduct against women, and it was in this context that the \#MeToo movement, sparked by accusations against the film producer Harvey Weinstein published

6 'The Politics of Anger', The Economist, 2 July 2016, https://www.economist.com/leaders /2016/o7/o2/the-politics-of-anger.

7 Vanessa Barford, 'Why Are Americans so Angry?', BBC News Magazine, 4 February 2016, https://www.bbc.com/news/magazine-35406324; Michelle Hackman, 'Donald Trump: "I Will Gladly Accept the Mantle of Anger,"' Vox, 14 January 2016, https://www.vox.com /2016/1/14/10773784/trump-debate-anger.

8 'Sanders Statement on Trump' Sen. Bernie Sanders, 9 November 2016, https://www.sanders .senate.gov/newsroom/press-releases/sanders-statement-on-trump.

9 Paul Krugman,Tweet, @paulkrugman, 9 November 2016, https://twitter.com/paulkrugman /status/796170345657069568.

10 Judith Butler interviewed on the 'Talking Politics' podcast, 17 November 2016, https:// www.talkingpoliticspodcast.com/blog/2016/1o-judith-butler. 
in the New York Times in October 2017, took off. ${ }^{11}$ Observers have explored the \#MeToo movement as an embodiment of 'women's anger.'12 In articulating this view, contemporary writers have drawn on the legacy of the pioneering second-wave feminist Audre Lorde, the black lesbian poet, essayist and activist who wrote with such intensity about anger and rage in the 1970s and 1980 os. 'My Black woman's anger', Lorde wrote in 1983, 'is a molten pond at the core of me, my most fiercely guarded secret. I know how much of my life as a powerful feeling woman is laced through with this net of rage.' 'How to train that anger with accuracy rather than deny it', she stated, had been one of the major tasks of her life. ${ }^{13}$

It is not surprising, in this context, that many have concluded that we live in an 'age of anger.' ${ }^{14}$ Rarely is any evidence offered, however, to support the assertion that people are in fact acting in anger. Why do commentators believe that people are 'angry' as opposed to, say, 'despairing', 'disappointed', or 'displeased'? Even when people do state that 'anger' or 'rage' is their main motivation, we rarely know what they mean by those emotion words, and whether they think of their emotions as motives, explanations, justifications or something else. Explaining political protest in terms of 'anger' becomes viciously circular if the term 'anger' is used simply to mean 'the emotional response that leads to political protest' or 'the emotion produced by deprivation'. Different individuals react with different emotions to injury and injustice. They may be sad or despairing, resentful or resigned, driven or determined. Political

11 Nadia Khomami, ‘\#MeToo: How a Hashtag Became a Rallying Cry against Sexual Harassment,' The Guardian, 20 October 2017, https://www.theguardian.com/world /2017/oct/2o/women-worldwide-use-hashtag-metoo-against-sexual-harassment; Clark Mindock, 'The Full List of Women Who Have Accused Donald Trump of Sexual Assault,' The Independent, 25 February 2019, https://www.independent.co.uk/news/world/ameri cas/us-politics/trump-sexual-assault-allegation-alva-johnson-claims-women-how-many -accused-kiss-a8796851.html; Jodi Kantor and Megan Twohey, 'Harvey Weinstein Paid Off Sexual Harassment Accusers for Decades,' The New York Times, 20 April 2018, https://www.nytimes.com/2017/10/o5/us/harvey-weinstein-harassment-allegations.html.

12 Soraya Chemaly, Rage Becomes Her: The Power of Women's Anger (London: Simon \& Schuster, 2018), 189-206; Rebecca Traister, Good and Mad: The Revolutionary Power of Women's Anger (New York: Simon \& Schuster, 2018), 157-205; Lilly Dancyger, ed., Burn It Down: Women Writing about Anger (New York: Seal Press, 2019); Megan Garber, 'All the Angry Ladies,' The Atlantic, 6 November 2017, https://www.theatlantic.com/entertainment/archive/2017/11/all-the-angry-ladies/545042/; R. O. Kwon, 'Finding Solace in the Words of Furious Women,' Literary Hub, 2 August 2017, https://lithub.com /finding-solace-in-the-words-of-furious-women.

13 Audre Lorde, 'Eye to Eye: Black Women, Hatred, and Anger (1983),' in The Audre Lorde Compendium: Essays, Speeches and Journals (London: Pandora, 1996), 191-219 (191).

14 Pankaj Mishra, Age of Anger: A History of the Present (London: Allen Lane, 2017). 
activism may be brought about by emotions other than so-called 'anger', while those who do identify with 'anger' may fail to take any effective political action, yet neither of those possibilities has received much consideration in recent commentary. ${ }^{15}$

Of the cases I have mentioned so far, it is the election of Donald Trump in 2016 for which we have the best evidence of voters' emotional states. In recent years, pollsters have increasingly asked people about their emotions as well as their opinions. The results, as ever, depend on how the question is put. Some polls require voters to state how angry they are on a range from 'very angry', through 'somewhat angry', to 'not at all angry'. A question offering several possible answers, all but one of which report some level of anger, gives, unsurprisingly, results suggesting high percentages of voter anger. ${ }^{16} \mathrm{~A}$ voter faced with such a question, feeling any kind of displeasure at all, is compelled to report it as 'anger'. Even within this limited scheme, however, it seems to have been voters who considered themselves 'dissatisfied but not angry' who were most important in securing Trump's victory. ${ }^{17}$ Furthermore, when given the chance to choose from a wider range of emotions, rather than placing themselves somewhere on a sliding 'anger' scale, in September 2016, 81 per cent of American voters described themselves as happy, and 79 per cent as optimistic, compared with 37 per cent as worried and, lowest of all, 14 per cent as angry. ${ }^{18}$

The available evidence does not suggest that we live in an age of anger, if by that we mean that people are reporting feeling more 'anger' than they used to, either relative to other emotion words, or in an absolute sense. However, we do live in an age of anger in another sense: political discourse, including written

15 This and other issues concerning the meanings of 'anger' past and present are explored in a podcast series of features, interviews and historical dramas, produced by the Queen Mary Centre for the History of the Emotions in 2019: 'The Sound of Anger', Soundcloud, https://soundcloud.com/user-357683788/sets/the-sound-of-anger.

CNN/ORC Poll on Views of Government, accessed 13 April 2019, https://www.cnn .com/2015/12/29/politics/cnn-orc-poll-full-results-obama-approval/index.html; 'Most Voters Are Still Angry - Rasmussen Reports,' accessed 13 April 2019, http:// www.rasmussenreports.com/public_content/politics/general_politics/january_2016 /most_voters_are_still_angry.

17 William Saletan, 'Trump's Voters Don't Support Deportation, and Other Surprises from the 2016 Exit Polls,' Slate Magazine, 9 November 2016, https://slate.com/news-and -politics/2016/11/debunking-myths-about-trump-voters-with-exit-polls.html.

'Anger' was the least frequently chosen emotion for all groups, although the percentage varied, with white college-educated voters the least likely to profess anger $(10 \%)$, followed by Hispanic working-class voters (11\%), white working-class voters $(18 \%)$ and then black working-class voters $(24 \%)$. 'Topline. Kaiser Family Foundation/CNN Working-Class Whites Report', 20 September 2016, 2, http://i2.cdn.turner.com/cnn/2016/images/og/20 /kff_cnn_wcw_topline_final.-.day2._9_2o.pdf. 
and broadcast journalism, and commentary on social media, is fascinated and preoccupied with 'anger'. This is one of the reasons why it is important to think further about what this preoccupation means, and especially what this 'anger' is with which we wrestle today. What does this modern English term mean, and what is the nature of its fascination for us?

\section{$3 \quad$ Words for Feelings}

The question of what the contemporary English word 'anger' actually means is rarely addressed in popular discussions, and the term remains ambiguous. ${ }^{19}$ Does the term 'anger' refer to a mental feeling of frustration? To a hardwired instinct for aggression against enemies? To a desire for revenge? To an outward behaviour like scolding or shouting? To a whole family of feelings and behaviours, perhaps including all of the above? Problems of multivalence and misunderstanding arise even before we confront issues of translation from and into other languages, past and present.

Two competing commentaries by scientists, published within days of the election of Donald Trump in 2016, offer a useful way into contemporary disagreements about the meaning of 'anger'. The neuroscientist R. Douglas Fields wrote a piece for the Scientific American blog explaining Trump's victory with reference to 'the emotion of anger'. This supposed entity, for Fields, had a singular evolutionary purpose, as 'the brain's threat detection mechanism', namely to put people into an inherited emotional state that helps 'protect our own tribe, and slaughter another tribe if necessary for our self-preservation.' ${ }^{20}$ Fields did not offer any evidence that voters were, in fact, in the grip of this state, nor did he explain why an ancestral capacity for tribal slaughter resulted in voting Republican for some people (under half of those who voted), but not for the majority, in whom murderous rage apparently did not hold sway.

19 For some useful texts illustrating the wealth of ideas, and disagreements, that abound in modern psychological attempts to define and explain anger and aggression, see James R. Averill, Anger and Aggression: An Essay on Emotion (New York: Springer, 1982); Carol Tavris, Anger: The Misunderstood Emotion (New York: Simon \& Schuster, 1982); Michael Potegal, Gerhard Stemmler, and Charles Spielberger, eds., International Handbook of Anger: Constituent and Concomitant Biological, Psychological, and Social Processes (New York: Springer, 2010).

$20 \quad$ R. Douglas Fields, ‘Trump's Victory and the Neuroscience of Rage,' Scientific American Blog Network, 10 November 2016, https://blogs.scientificamerican.com/mind-guest-blog /trump-s-victory-and-the-neuroscience-of-rage/. 
Two days after the blog post by Fields promoting this stark view that 'anger' is the name of an irresistible evolved 'fight' mechanism, an op-ed for the New York Times by the psychologist of emotion Lisa Feldman Barrett offered a different view. For her, the term 'anger' was the name not of a single hard-wired instinct, but rather of a 'diverse population of experiences and behaviors' including bitterness, hostility, and rage, as well as wrath, grumpiness and scorn. 'The varieties of anger', wrote Feldman Barrett, 'are endless.'. ${ }^{21}$ This theoretical approach to emotions as psychological constructions, in which language, education and situated personal experience shape 'core affect' into many culturally specific forms, is one that has been championed for decades by Feldman Barrett, James A. Russell and others. ${ }^{22}$ This approach is relatively genial to historians of emotions - probably more so than versions of the theory of 'basic emotions' championed by Paul Ekman and those with a similar outlook. ${ }^{23}$ Feldman Barrett's reference to 'angers' in the plural is a useful corrective to the idea that 'anger' names a single transhistorical emotion, as is another recent scientific study arguing that 'anger' names a feeling state that should be distinguished more carefully from related emotions such as 'indignation' and 'resentment'.

Studies in historical linguistics also support pluralism. Daria Izdebska has explored the words for anger-like emotions in Old English and Middle English, tracing the semantic histories of terms including yrre, gram, wod, wroth and torn. Following Cliff Goddard, Izdebska criticises the attempt to capture the mental lives of other cultures in modern English terms as a form of 'terminological ethnocentrism, ${ }^{25}$ Anna Wierzbicka has also written prolifically about

21 Lisa Feldman Barrett, 'The Varieties of Anger,' The New York Times, 12 November 2016, https://www.nytimes.com/2016/11/13/opinion/sunday/the-varieties-of-anger.html.

Agnes Moors, 'Integration of Two Skeptical Emotion Theories: Dimensional Appraisal Theory and Russell's Psychological Construction Theory,' Psychological Inquiry 28, no. 1 (2017): 1-19; James A. Russell, 'Core Affect and the Psychological Construction of Emotion,' Psychological Review 110, no. 1 (2003): 145-72; Carlos Crivelli et al., 'The Fear Gasping Face as a Threat Display in a Melanesian Society,' Proceedings of the National Academy of Sciences 113 (1 November 2016): 12403-07.

23 Ruth Leys, 'How Did Fear Become a Scientific Object and What Kind of Object Is It?,' Representations 110, no. 1 (2010): 66-104; Ruth Leys, The Ascent of Affect: Genealogy and Critique (Chicago: University of Chicago Press, 2017).

24 M. Miceli and C. Castelfranchi, 'Anger and its Cousins,' Emotion Review 11, no. 1 (2019): $1-26$.

25 Daria Izdebska, 'The Curious Case of TORN: The Importance of Lexical-Semantic Approaches to the Study of Emotions in Old English,' in Anglo-Saxon Emotions: Reading the Heart in Old English Language, Literature and Culture, ed. Alice Jorgensen, Frances McCormack, and Jonathan Wilcox (Farnham: Ashgate, 2015), 53-74 (58). See also Caroline Gevaert, 'The Anger is Heat Question: Detecting Cultural Influence on 
emotions from a linguistic point of view, making similar arguments, which are captured in the title of her book, Imprisoned in English: The Hazards of English as a Default Language. In a chapter on 'anger', 'disgust' and Ekman's theory of basic emotions, Wierzbicka mentions several languages which lack any direct equivalent to the English term 'anger', looking especially at Wut and Zorn in German (which, incidentally, are both related to early English terms studied by Izdebska) ${ }^{26}$

Further evidence of the instability of 'anger' can be found in anthropology. One of the classic ethnographic studies of emotion in the twentieth century was an account by Jean L. Briggs of the emotional dynamics of an Inuit settlement in a remote arctic region. Never in Anger: Portrait of an Eskimo Family documented not only the prevailing emotional regime among the Utku people but also Briggs's attempts, and repeated failures, to conform to it. ${ }^{27}$ Briggs took an interest in the emotional terminology of the Utku. For the sake of convenience, she generally referred in her book to people displaying 'anger' or 'bad temper'. However, these English labels did not have direct equivalents in the Utku dialect. Never In Anger was a book not only about a culture with a strong apparent aversion to what Briggs and her American contemporaries in the 1960s called 'anger' but also about one with no equivalent concept of 'anger'. In a linguistic appendix to her study, Briggs suggested nine broad emotional 'syndromes', and arranged Utku terms under those headings. One of these was 'Ill Temper and Jealousy', which encompassed eight different Utku terms, five of which related to aggression and hostility, and three to possessiveness

the Conceptualization of Anger through Diachronic Corpus Analysis,' in Perspectives on Variation: Sociolinguistic, Historical, Comparative, ed. Nicole Delbecque, Johan van der Auwera, and Dirk Geeraerts (Berlin: Mouton de Gruyter, 2005), 195-208; Caroline Gevaert, 'The Evolution of the Lexical and Conceptual Field of ANGER in Old and Middle English,' in A Changing World of Words: Studies in English Historical Lexicography, Lexicology and Semantics, ed. Javier E. Diaz Vera (Amsterdam: Rodopi, 2002), 275-99; Dirk Geeraerts, Caroline Gevaert, and Dirk Speelman, 'How Anger Rose: Hypothesis Testing in Diachronic Semantics,' in Current Methods in Historical Semantics, ed. Kathryn Allan and Justyna A. Robinson (Berlin: De Gruyter Mouton, 2011), 73-109.

26 Anna Wierzbicka, Imprisoned in English: The Hazards of English as a Default Language (New York: Oxford University Press, 2013), ch. 7; see also Anna Wierzbicka, "Sadness" and "Anger" in Russian: The Non-Universality of the So-Called "Basic Human Emotions,"' in Speaking of Emotions: Conceptualisation and Expression, ed. Angeliki Athanasiadou and Elżbieta Tabakowska (Berlin: Mouton de Gruyter 1998), 3-28; Anna Wierzbicka, Emotions Across Languages and Cultures: Diversity and Universals (Cambridge: Cambridge University Press, 1999).

27 Jean L. Briggs, Never in Anger: Portrait of an Eskimo Family (Cambridge, MA: Harvard University Press, 1970), 74, 329. 
or unhappiness of other kinds. ${ }^{28}$ The terms were largely to do with outward behaviours, and Inuit languages seem not to have an equivalent category to the modern English concept of 'emotions' at all, and hence their moral and psychological beliefs about shouting, attacking, and hostility were not based on the same model of the mind used in modern Anglophone psychology. ${ }^{29}$

It is also important to remember that modern English, just as much as Old English, German, Utku and other languages, has more than one word for anger-related emotions. In addition to 'anger', there are 'ire', 'wrath', 'fury', 'vengeance,' 'hatred', 'frustration', 'resentment', 'rage', 'bile', 'irritation' and many more. Samuel Johnson's foundational 1755 dictionary sketched an interconnected web of definitions. 'Fury' was, first, 'madness', and secondly 'Rage; passion of anger; tumult of mind approaching to madness'. In its turn 'rage' meant 'violent anger, vehement fury', while 'anger' was defined with a quotation from John Locke, as 'uneasiness or discomposure of the mind, upon the receipt of any injury, with a present purpose of revenge. ${ }^{30}$ Some authors in the eighteenth century, including the Scottish philosopher Thomas Reid, used 'resentment' rather than 'anger' as their favoured term for a strong and vengeful frame of mind..$^{31}$

We can form a further impression of the histories of these terms from the millions of pages of historical English-language texts accessible via the Google Books Ngram Viewer. A search for some of the more common English words in this semantic network - 'anger', 'rage', 'wrath', 'resentment', and 'fury' - from 1750 to 2008 produces a graph showing three stages of linguistic usage (figure 1 ).

In the first stage, from around 1750 to 1850 , 'resentment' is the most commonly used of the terms, with 'anger' and 'wrath' the least common. ${ }^{32}$ Between the 1760 s and the 1780 os, 'resentment' is used well over twice as frequently as 'anger'. Then, from 185 o to about 1965 , 'anger' emerges as, and remains, the

28 Briggs, Never in Anger, 328-37.

29 Michael Fortescue, 'The Semantic Domain of Emotion in Eskimo and Neighbouring Languages,' in The Lexical Typology of Semantic Shifts, ed. Päivi Juvonen and Maria Koptjevskaja-Tamm (Berlin: De Gruyter, 2016), 285-333.

30 Samuel Johnson, A Dictionary of the English Language, 2 vols (London: Printed by W. Strahan, for J. and P. Knapton; T. and T. Longman; C. Hitch and L. Hawes; A. Millar; and R. and J. Dodsley, 1755), s.vv. 'fury', 'rage', 'anger'.

31 Thomas Reid, Essays on the Active Powers of Man (Edinburgh and London: John Bell and G. G. J. \& J. Robinson, 1788).

32 For a valuable article which pays attention to a range of terms used for sinful states of passion, ire and resentment in early modern English letters, while giving interpretive prominence to a somewhat reductive concept of 'anger', see Linda A. Pollock, 'Anger and the Negotiation of Relationships in Early Modern England, The Historical Journal 47, no. 3 (September 2004): 567-90. 


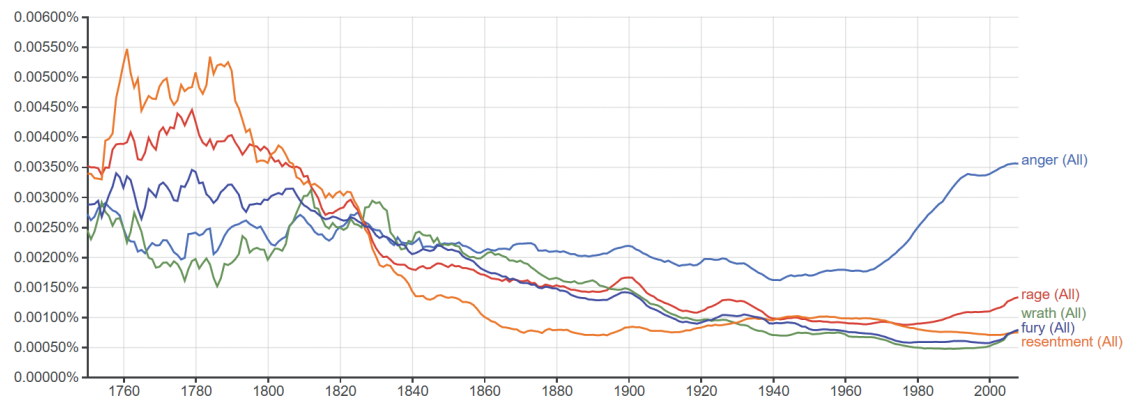

FIGURE 1 Graph generated by Google Books Ngram Viewer showing relative frequency of 'anger', 'rage', 'wrath', 'fury' and 'resentment' in English-language texts, 1750-2008.

most frequently used of the five terms, the rest of which gradually dwindle in popularity. By 1965, 'anger' was used twice as often as the most popular of the other words. Then, in the third and final stage, from the 196os onwards, 'anger' rises steeply in frequency until it is about three times as frequent in usage as the next most common term, 'rage'. ${ }^{33}$ Although such evidence on its own is suggestive rather than definitive, this picture is consistent with one in which 'anger' emerged as a newly dominant psychological category in the late nineteenth century, and then, from the 196os until today, came to dominate still further, in a way that has led to a relative impoverishment of the affective vocabulary for feelings in the furious family in modern English usage.

So, historians of emotions can join forces with psychologists, linguists, and anthropologists in arguing against the essentialism, ethnocentrism and anachronism that is embodied in the assumption that the modern English word 'anger' names an unchanging, universal emotion. The cumulative destructive case seems very strong. But how can we begin to make a more constructive argument about how a history of this problematic and multivalent term could be undertaken?

The method that I suggest is a kind of anatomical genealogy. It is anatomical in that it looks at the range of loosely connected phenomena that modern users of the term 'anger' variously believe it refers to, and seeks to prise them apart from each other. So, for instance, one component of the reality we need to understand as historians of 'anger' is made up of the words, in English and other languages, that 'anger' is supposed to be related to - whether as a synonym, near-synonym, or translation. Then there are philosophical, religious

33 Google Ngram Viewer, accessed May 11, 2019, 'anger, wrath, rage, resentment, fury', caseinsensitive, 1750-2008, from corpus 'English', with smoothing of 3, https://books.google .com/ngrams/. 
and scientific concepts, such as the desire for revenge, or the evolution of animal instincts, or beliefs about morality and sinfulness, that have been used in spelling out the meanings of the terms in the semantic network around 'anger'. Looking beyond the world of verbal reference, modern uses of 'anger' have also had a visual component, in which the word is connected with images, including representations of particular human facial expressions and bodily gestures. Having used this anatomical approach to tease apart different components, the method is genealogical in that it traces back, from the present, the ancestry of each of these components. The main criterion for inclusion in this suggested genealogy of 'anger' is demonstrable cultural ancestry, through processes of transmission, translation and descent to modern referents of that term. Anatomically separating these components from each other allows us to look at their distinct histories, including considerable discontinuities, without losing the focus which our interest in modern uses of 'anger' affords.

Ancient Ancestors: Revenge, Bloodlust, Pleasure, and Passion

Martha C. Nussbaum's account of 'anger', in Anger and Forgiveness: Resentment, Generosity, Justice, forms one recent link in a chain of philosophical thought about revenge that we can trace back to the ancient world. Nussbaum's definition of 'anger' is similar to John Locke's, cited by Johnson in 1755, and both are descended from ancient philosophical sources. Nevertheless, we should not overstate the continuities, for reasons that will become clear when we look in more detail at the key ancient texts themselves, including works by Homer, Aristotle and Seneca. ${ }^{34}$ These ancient accounts focused on vengeful violence, sometimes as something virtuous and pleasurable, sometimes as the result of errors and diseases of the mind. In either case, the translation of certain ancient Greek and Latin terms as 'anger' in modern English has simultaneously secured a superficial chain of genealogical descent, while repeatedly obscuring deeper differences of meaning, connotation, experience, and worldview.

Nussbaum's account of what 'anger' means today is built upon Aristotle's account of a passion he called orgē. The key components of orgē-like 'anger' for Nussbaum are not bodily arousal or facial expressions but thoughts, especially the belief that I or someone I care about has been wronged or injured, combined with a crucial desire for 'payback' or revenge. For Nussbaum, the

34 In developing the analysis in this section, I have been helped especially by William V. Harris, Restraining Rage: The Ideology of Anger Control in Classical Antiquity (Cambridge, MA: Harvard University Press, 2001). 
presence of 'anger' is something to be determined primarily by conceptual analysis. If the mental state has the stipulated logical structure - perceived injury, pain, and a desire for revenge - then it is a state of 'anger', and otherwise not, regardless of whether the person looks angry, thinks they are angry or behaves angrily. 35

In wider contemporary discussions of 'anger' in politics and psychology, unlike many philosophical discussions of the term, 'revenge' is rarely mentioned. The idea of a hard-wired animal 'fight' response, although it can be linked to ideas of revenge, need not be; at its heart is a more raw and unfocused aggression. The idea of revenge did not feature in the meanings of the anger-related terms explored by Jean Briggs in her study of the Utku, nor is it prominent in modern discussions of the power of political anger as a motor for protest and activism. In the classical sources from which modern theorists of 'anger' most often claim descent, however, narratives of revenge, and related notions of honour, were central. For those of us, myself included, who do not consider the desire for revenge to be a major part - or frequently any part at all - of the states we experience as 'anger' today, this is a major difference of meaning, and a reason to resist Nussbaum's idea that orge and 'anger' name the same, single state.

A further kind of discontinuity emerges when we turn to Homer. Although modern commentators have sometimes suggested that the Iliad was a tale of two episodes of 'anger', the first directed by Achilles at Agamemnon and the second by Achilles at Hector, in fact neither element of the story is well understood in this way. ${ }^{36}$ At the opening of the Iliad, Achilles believes his honour has been insulted by Agamemnon and, in retaliation, refuses to fight against the Trojans. It was that insulted refusal and withdrawal that was called mênis in the opening word of the poem. Mênis was an unusual term, used only twelve times in the Iliad, eight to refer to one of the gods, and four to refer to Achilles' antagonism towards Agamemnon. ${ }^{37}$ Mênis was a long-lasting cosmic enmity

35 Martha C. Nussbaum, Anger and Forgiveness: Resentment, Generosity, and Justice (New York: Oxford University Press, 2016), 14-56. See also Thomas Dixon, 'What Is Anger? 1. Martha Nussbaum,' The History of Emotions Blog, 22 July 2016, https://emotionsblog .history.qmul.ac.uk/2016/o7/what-is-anger-1-martha-nussbaum/.

36 For a discussion of this interpretation, see Glenn W. Most, 'Anger and Pity in Homer's Iliad,' in Ancient Anger: Perspectives from Homer to Galen, ed. Susanna Braund and Glenn W. Most (Cambridge: Cambridge University Press, 2004), 50-75.

37 It is possible to search and analyse the Greek terms used in the text via The Chicago Homer, 'a multilingual database that uses the search and display capabilities of electronic texts to make the distinctive features of Early Greek epic accessible to readers with and without Greek', ed. Ahuvia Kahane, Martin Mueller, Craig Berry, and Bill Parod, accessed 12 May 2019, http://homer.library.northwestern.edu. 
unavailable to normal mortals. One senses it could have gone on for the rest of Achilles' life if he had not had a change of heart. In that respect, mênis is not well captured by 'anger', nor even by 'wrath' which suggests a more temporary state. The mênis of Achilles seems more like a kind of cold hatred, or even a cosmic, heroic sulk. Scholars including Leonard Muellner, have argued that mênis differed from modern psychological 'anger' by referring to something grander and, to us, weirder - a cosmic sanction for taboo behaviour. It is a shame, given Muellner's arguments to this effect, that his book on the subject is titled The Anger of Achilles: Mênis in Greek Epic. ${ }^{38}$ An understandable desire to engage modern readers by using emotional terms they recognise has resulted in a title being chosen that contradicts the argument of the book and collapses the considerable distance between our world and Homer's.

Turning to the second half of the Iliad, Achilles is gripped by sorrow and grief after the death of his beloved friend Patroclus at the hands of Hector. Achilles' grief drives him back to war, where he ultimately meets and kills Hector. Achilles, sorrowing madly for Patroclus, tells Agamemnon to 'call up the wild joy of war', vowing not to eat or drink until he has avenged the death of his friend. 'You talk of food? I have no taste for food - what I really crave is slaughter and blood and the choking groans of men!' Achilles is described as 'yearning now to glut with Hector's blood' and he fights 'like a frenzied god, his heart racing with slaughter'. After capturing twelve young Trojans, whom he will later burn alive as sacrifices on the funeral pyre of Patroclus, Achilles returns eagerly to the fray, 'insane to hack more flesh'. When Hector is defeated and begs for his life, Achilles responds, 'Would to god my rage, my fury would drive me now to hack your flesh away and eat you raw - such agonies you have caused me!'39

If 'anger' fails to capture the long-lasting, godlike hatred of mênis, it also misses the mark here. 'Anger', or even 'rage', sound too tame, too normal, to describe the frenzied bloodlust of the grief-stricken Achilles. In fact, the mental state of the grieving Achilles seems to me less like 'anger' and more like something observed by the anthropologists Michelle and Renato Rosaldo among the head-hunting Ilongot tribe of the Philippines in the 196os. The Ilongot used

38 Leonard Muellner, The Anger of Achilles: Mênis in Greek Epic (Ithaca, NY: Cornell University Press, 2004); see also Thomas R. Walsh, Fighting Words and Feuding Words: Anger and the Homeric Poems (Lanham: Lexington Books, 2005).

Homer, The Iliad, ed. Bernard Knox, trans. Robert Fagles (Harmondsworth: Penguin, 1990), 493, 495, 506, 521, 553. Quotations from Book 19, ll. 179, 254-56; Book 2o, ll. 92-93; Book 21, ll. 21-22, 37; Book 22, ll. 408-o9; Greek terms compared via The Chicago Homer online and the Loeb Classical Library edition: Homer, The Iliad, ed. and trans. A. T. Murray, rev. William F. Wyatt, 2 vols (Cambridge, MA: Harvard University Press, 1999). 
the term 'liget' to describe a painful, intense energy experienced in bereavement which finds its catharsis in extreme, homicidal vengeance, in their case 'taking the head' of a man in another tribe. ${ }^{40}$ Among the ancient Greek terms used in Homer's epic to describe the sorrowful fighting fury of Achilles, the terms menos, thumos and huperthumos referred to an energetic force, spirited ferocity, or hyper-fury. The blood-thirsty Achilles who slaughters the Trojans is driven by an unbearable, frenzied, grief which is not well captured by the relatively tame modern psychological term 'anger'.

We should give up on the quest for an 'anger'-shaped key to the Iliad. Doing so allows us to offer more historically sensitive readings of that text. ${ }^{41}$ We find, in the character of Achilles, powerful mental states, a desire to avenge wrongs, an ability for strong hatred, deep grief and frenzied violence. The mental states of Achilles as imagined by Greek performers and their audiences almost three thousand years ago, and the terms used to name them, are the distant ancestors of our modern emotional words and feelings, but we should beware of the distortions produced by translating the text into modern psychological terms. It is often better to use unfamiliar or even archaic terms, or to leave the key terms in their original language, in order to demonstrate that discontinuity. ${ }^{42}$

So far, I have noted that modern notions about 'anger' do not tend to give great prominence to revenge, while vengeance is the central focus of orge, and also that the passions of Achilles, sometimes described as 'anger', are better described as a cosmic sulk followed by a grief-stricken bloodlust. A further discontinuity arises when we think about pleasure and pain. In Aristotle and the Stoics, orge was normally defined not, as one might expect, as a negative feeling directed towards a past wrong, but rather as a state that looked forward to a future good, namely the pleasure that would arise from the taking of revenge on the perpetrator of the injury. ${ }^{43}$ It was not only that the revenge would be enjoyable, but that even thinking about it in advance was a thrill. In his Rhetoric, Aristotle looked back to the world of the Iliad, quoting from a speech in which Achilles mourned the prevalence of strife in the world, referring to the 'bitter

40 Michelle Z. Rosaldo, Knowledge and Passion: Ilongot Notions of Self and Social Life (Cambridge: Cambridge University Press, 1980); Renato Rosaldo, Culture and Truth: The Remaking of Social Analysis (London: Routledge, 1993), 1-21.

41 For a recent, complementary analysis of the emotional dynamics of the Iliad, see Rob Boddice, $A$ History of Feelings (London: Reaktion, 2019), 20-35.

42 Rob Boddice has made similar points, suggesting that sometimes emotion terms in other languages are better left untranslated, and noting that modern English translations of classical, and other, terms can be highly misleading, arguing that through such translations, 'ancient historical writing has been made to serve presentist preoccupations'; Boddice, History of Feelings, 35, 44-45.

43 Nussbaum, Anger and Forgiveness, 21. 
gall [cholos], sweeter than dripping streams of honey, that swarms in people's chests and blinds like smoke. ${ }^{44}$ Both Aristotle and Homer may have been using poetic licence, but there is good reason to think they were describing something different from what people think of as 'anger' today, when they wrote of the sweet sensual pleasures of cholos and orgè.

The longest and most influential ancient text in the genealogy of ideas about vengeance, produced in the centuries after Aristotle, was De ira by the Roman statesman and Stoic philosopher Seneca. ${ }^{45}$ The treatise was composed in the first century CE, more than seven hundred years after the Iliad was written down, four centuries after the works of Aristotle, and in Latin rather than Greek. Nonetheless De ira was in the same cultural lineage as those earlier works. Seneca quoted from both Homer and Aristotle, the latter repeatedly, and his definition of ira had a certain amount in common with Aristotle's orgē. For Seneca, ira was 'the desire to punish the person by whom you reckon you were unjustly harmed. ${ }^{46}$ The examples Seneca chose showed that ira, like orge, was focused primarily on revenge, and was an intense and powerful passion experienced within the framework of an honour culture. Robert A. Kaster states that Seneca's ira may resemble 'rage' more than 'anger' in modern English usage, while being synonymous with neither. I would add that 'vengeance' or 'wrath' might be closer. Again, however, differences between modern so-called 'anger' and ancient passions are collapsed by the decision made by modern translators, including Kaster himself, to render ira as 'anger' in their English versions of Seneca's text. ${ }^{47}$

Seneca's treatise was uncompromising in its opposition to ira, in all its forms, as a deranged and dangerous passion. Having listed some of its various incarnations, Seneca concluded of ira that there were 'a thousand other varieties of this polymorphous evil. ${ }^{48}$ For Seneca, as for the other Stoics, passions were described as moral errors, cognitive mistakes and sicknesses of the soul,

44 Homer, The Iliad, ed. Knox, trans. Fagles, 471, Book 18, l. 128; Harris, Restraining Rage, $55^{-65}$.

45 On Seneca's philosophy and its place alongside other ancient proponents of Stoic ideas about the passions, see Lucius Anneaus Seneca, Anger, Mercy, Revenge, trans. Robert A Kaster and Martha C. Nussbaum (Chicago: University of Chicago Press, 2010); Harris, Restraining Rage, ch. 15; Marcus Tullius Cicero, Cicero on the Emotions: Tusculan Disputations 3 and 4, ed. Margaret Graver (Chicago: University of Chicago Press, 2002); Margaret R. Graver, Stoicism and Emotion (Chicago: University of Chicago Press, 2007); Martha C. Nussbaum, The Therapy of Desire: Theory and Practice in Hellenistic Ethics (Princeton: Princeton University Press, 1994).

46 Seneca, Anger, Mercy, Revenge, 16, 1.2.3b.

47 Seneca, Anger, Mercy, Revenge, 99, n. 14.

48 Seneca, Anger, Mercy, Revenge, 18, 1.4.2-3. 
to be contrasted with reason and virtue, which were the only real goods. The two main cognitive mistakes involved for Seneca in ira were, first, the belief that a person had genuinely been harmed (that is their virtue or reason had been diminished), and secondly the belief that revenge would make things better. The first was almost always false, the latter absolutely always false, Seneca believed. ${ }^{49}$ Another distinctive aspect of Seneca's theory was that he thought of ira not as a single experience but as an unfolding process, during which a person's conscious rational mind assented, in a blameworthy way, to the impression that they had been harmed and should take revenge. This assent allowed the fully fledged madness of ira to take over, and then all was lost, from a Stoical point of view..$^{50}$

We can be confident that ancient Greeks and Romans did not experience the modern emotion of 'anger', partly because the overarching mental and moral frameworks within which they lived, felt and were moved differed so fundamentally from ours. Writers such as Homer and Euripides composed their songs and dramas in an era before there was any generalised category in which rage, wrath, grief and other movements of soul and body were grouped together. From around the fourth century ВСЕ onwards that changed, and philosophers began to group those movements together under the category of pathe, or the 'passions' of the soul. ${ }^{51}$ This was an important milestone in the history of Western thinking about passions, as was the emergence of a new theoretical category of 'the emotions', over two millennia later, within which theories of 'anger' have developed since the nineteenth century. ${ }^{52}$ Seneca's moral-philosophical understanding of ira as a passion, a mistake and a disease makes it distinct from dominant modern understandings of 'anger' as a human emotion, which tend to use the term as part of a psychological or medical rather than moral or ethical framework, and if anything tend to see it positively as natural and healthy. So, while in one sense Seneca's De ira marked the beginning of the prehistory of modern 'anger', and belongs in its ancestry, it is clear that both in its understanding of the mind, and in the concepts it deploys of

49 Seneca, Anger, Mercy, Revenge, 14-34, Book 1 as a whole represents a statement of the Stoic view, which contradicts the Aristotelian view that the desire for revenge, in moderation, can be rational and virtuous.

$5^{\circ} \quad$ Seneca, Anger, Mercy, Revenge, 34-37, 2.1-2.4.

$5^{1} \quad$ Harris, Restraining Rage, 84-87, 401-02.

52 On the long history of the meanings of 'passions' in comparison with other terms, including 'affections' and 'emotions', see Juanita Feros Ruys, Michael W. Champion, and Kirk Essary, eds, Before Emotion: The Language of Feeling, 400-1800 (New York: Routledge, 2019); Thomas Dixon, From Passions to Emotions: The Creation of a Secular Psychological Category (Cambridge: Cambridge University Press, 2003); Dixon, “Emotion”: The History of a Keyword in Crisis.'. 
honour, status, vengeance, madness and reason, it offers a map of minds that were different from our own.

In the history of emotions, the history of ideas meets the history of the body. As we continue to pull apart the components of modern 'anger', the history of visibly enraged human forms, from the Middle Ages to the present, reinforces the sense of discontinuity that has already emerged from examining the ancestries of words and ideas. The physical performances and gestures that have accompanied, embodied and made visible irate passions and angry emotions are not best thought of either as secondary expressions of something autonomous and mental, nor as simple physical reflexes. As Monique Scheer has put it, such bodily movements 'are more fruitfully thought of as habits emerging where bodily capacities and cultural requirements meet'. Emotions change over time, Scheer points out, not only because the expectations, words, and concepts verbal and intellectual machinery of the kind that I have been surveying so far in this essay - evolve, but also because 'the practices in which they are embodied, and bodies themselves, undergo transformation.53 The genealogy of bodily and visible aspects of ire, wrath, rage and anger bear out these observations. The enraged body is as historically constituted as the irate mind.

Those of us living in the age of modern psychology are habituated to the idea, forcefully made by both Charles Darwin and William James in the late Victorian period, that our emotions, in some sense, are identical with their embodiments. Indeed, it may be our immersion in that thought-world that makes it hard for some of us to accept a conceptual definition of 'anger' like Nussbaum's, which practically ignores bodily dimensions. Darwin wrote, in his 1872 book about expression, that 'Most of our emotions are so closely connected with their expression, that they hardly exist if the body remains passive'. 'So a man may intensely hate another', Darwin went on, 'but until his bodily frame is affected, he cannot be said to be enraged'. ${ }^{44}$ Similarly, William James

53 Monique Scheer, 'Are Emotions a Kind of Practice (and Is That What Makes Them Have a History)? A Bourdieuian Approach to Understanding Emotion,' History and Theory 51, no. 2 (2012): 193-220 (202, 220); see also Dolores Martin-Moruno and Beatriz Pichel, eds., Emotional Bodies: The Historical Performativity of Emotions (Urbana: University of Illinois Press 2019).

54 Charles Darwin, The Expression of the Emotions in Man and Animals (London: Murray, 1872), 239; see also Dixon, From Passions to Emotions, 159-79; Thomas Dixon, Weeping Britannia: Portrait of a Nation in Tears (Oxford: Oxford University Press, 2015), 185-98. 
insisted in 1884 that the bodily changes that occur do not express an emotion, but are the emotion. Without a flushed face, dilated nostrils, clenched teeth and a vigorous impulse to action, James reasoned, there can be no rage, merely some pallid and purely intellectual state which could not be considered an emotion. ${ }^{55}$

Through the work of Paul Ekman and his colleagues in the later twentieth century, a new, distinct theory of 'basic emotions' became widely known, according to which each of a small number of supposedly universal emotions, including one called 'anger', was an affect programme with its own physiological fingerprint and facial expression. ${ }^{56}$ For modern basic emotions theorists, each episode of 'anger' is a fleeting phenomenon combining a state of physiological arousal, interpreted as an evolved 'fight' response, with a characteristic facial expression. This is a key tenet of the basic emotions faith: each true emotion has a distinctive and universal facial expression. However, even basic emotion theorists use at least two different 'anger' faces in their experiments: a wideeyed, pursed-lipped one and also a squinty-eyed, teeth-baring one (figure 2). Other studies use so-called 'anger' faces that are different from either of these, for instance combining pursed lips with squinting eyes or bared teeth with wide eyes. ${ }^{57}$ This fact already undermines the strongest form of the claim that 'anger' is the name of a single basic emotion. The theory is further undermined

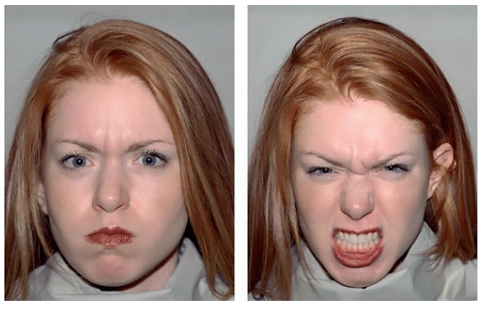

FIGURE 2

Two anger faces from the 'NimStim' set of facial expressions, posed by actors and photographed for use in psychology experiments. Image cropped from FSTC: Face Stimulus and Tool Collection, accessed April 15, 2019, https://rystoli.github.io/FSTC.html.

55 William James, 'What is an Emotion?,' Mind 9 (1884), 188-205 (194); see also Dixon, From Passions to Emotions, 204-30.

56 Paul Ekman and Daniel Cordaro, 'What is Meant by Calling Emotions Basic,' Emotion Review 3, no. 4 (2011): 364-70; Crivelli et al., 'The Fear Gasping Face'; Potegal, Stemmler, and Spielberger, eds, International Handbook of Anger; Leys, Ascent of Affect.

FSTC: Face Stimulus and Tool Collection, accessed 15 April 2019, https://rystoli.github. io/FSTC.html; Nim Tottenham et al., 'The NimStim Set of Facial Expressions: Judgments from Untrained Research Participants,' Psychiatry Research 168, no. 3 (2009): 242-49; José-Miguel Fernández-Dols and James A. Russell, eds, The Science of Facial Expression (New York: Oxford University Press, 2017). 
by empirical studies that have found that the production and recognition of a supposedly universal 'anger' face is not, in fact, universal. ${ }^{58}$

Our faces and bodies undoubtedly have a role not only in communicating but also in creating and maintaining our feelings, but it is not a simple role, and history can be used to contextualise and critique any reductive physicalist approach to emotions and their expression. An arrangement of the face, like a word in a language, takes its meaning from both its cultural history and its immediate context. In real life, we encounter a facial expression not in posed, immobile isolation, but as attached to a particular body, of a particular person, who is doing and saying particular things, some of whose recent life story we typically know. The face is rarely the dominant factor in these complex situations, and historically the focus on the individual face as the key to emotional legibility is a recent, Western development. The fact that each historical era, up to and including our own, has produced and codified its own different bodily language of expression, substantially different from what went before, backed up with the latest theories, and communicated in different visual media, is an argument against the universality of any of them. Here again history can collaborate with the sciences in crafting a more realistic theory of emotions. ${ }^{59}$

We can trace a rich strand of the visual prehistory of anger-related states starting with medieval Christian visions of ira as one of the deadly sins. ${ }^{60}$ The Dutch painter Hieronymus Bosch depicted ira within a cycle of the seven deadly sins, and the four last things - death, judgement, heaven and hell. His tabletop painting, produced around 1500, portrayed passions not primarily through

$5^{8}$ For informed empirical and theoretical perspectives on the psychology of facial expression, see Sherri C. Widen, 'Children's Interpretation of Facial Expressions: The Long Path from Valence-Based to Specific Discrete Categories,' Emotion Review 5, no. 1 (2013): 72-77; Potegal, Stemmler, and Spielberger, eds, International Handbook of Anger, Part III; Fernández-Dols and Russell, Science of Facial Expression; James M. Carroll and James A. Russell, 'Do Facial Expressions Signal Specific Emotions? Judging Emotion from the Face in Context,' Journal of Personality and Social Psychology 70, no. 2 (1996): 205-18.

59 On the further potential for such collaborations, see a forthcoming special section of Emotion Review on the history of emotions, to be published in 2020, edited by Rob Boddice.

6o On the history of the idea of bad thoughts and deadly sins as developed in early Christian thought, see Richard Sorabji, Emotion and Peace of Mind:From Stoic Agitation to Christian Temptation (Oxford: Oxford University Press, 200o), esp. chs 22 and 23; for a wider discussion of anger as a 'deadly sin,' including Christian, philosophical and Buddhist perspectives, see Robert A. F. Thurman, Anger: The Seven Deadly Sins (New York: Oxford University Press, 2004). For a substantial and wide-ranging discussion of anger-like states in connection with medieval and early modern humours, passions, bodies and faces, see Elena Carrera, 'Anger and the Mind-Body Connection in Medieval and Early Modern Medicine,' in Emotions and Health, 1200-1700, ed. Elena Carrera (Leiden: Brill, 2013), 95-146. 
facial expressions, nor even bodily gestures, but instead through everyday scenes. The scenario for ira shows two drunken men brawling outside a tavern. A woman is trying keep them apart. The man on the left is wearing a piece of furniture, presumably thrown at him by his antagonist, who is carrying a drink, and brandishing his sword. This is was a recognisable image of ira in medieval Europe, and was part of a warning against sinful behaviour that could lead to hell. Bosch's painting was, then, a work of religious instruction and social commentary. ${ }^{61}$ In the following centuries, many European artists followed Bosch's example, depicting ira as a propensity to hot-headed, often drunken violence. In the 1620 s the Flemish painter Adriaen Brouwer represented ira in the figure of a man drawing his sword, at the same time as disturbing a table and jug in what appears to be the interior of a tavern. It is the scenario as a whole rather than the face that tells the story. ${ }^{62}$

Leonardo da Vinci developed his thoughts about painting the passions in the notebooks he kept in the 153 os and 1540s, which were published as a Treatise on Painting the following century. In the section on how to depict una figura irata - an irate figure - Leonardo followed in the moralistic tradition of depicting ira as a situation rather than a feeling. The irate man should be shown, he wrote, holding another man down on the ground, 'by the hair of his twisted head, his knees on the other's ribs, and his right arm raising his fist on high'. Leonardo specified further that the irate man's hair should stand on end, his teeth be clenched, and his neck swollen. ${ }^{63}$ It was as if Seneca's raging madman were taking part in Bosch's drunken brawl.

There is, then, some continuity between ancient, medieval and Renaissance depictions of the visible varieties of ira. They focus on a violent situation and a moral narrative of sin, vice and punishment. The key moment of discontinuity in this story arrives in the seventeenth century in the work of Charles Le Brun, a prominent figure in the court of Louis XIV. As director of artistic education,

61 For a fuller discussion of the image and its meanings, see Laura D. Gelfand, 'Social Status and Sin: Reading Bosch's Prado Seven Deadly Sins and Four Last Things Painting,' in The Seven Deadly Sins: From Communities to Individuals, ed. Richard Newhauser (Leiden: Brill, 2007), 229-56; Henry Luttikhuizen, 'Through Boschian Eyes: An Interpretation of the Prado Tabletop of the Seven Deadly Sins,' in Sin in Medieval and Early Modern Culture: The Tradition of the Seven Deadly Sins, ed. Richard Newhauser (York: York Medieval Press, 2012), 261-81; Larry Silver, Hieronymus Bosch (New York: Abbeville Press, 2006), 305-18.

62 Jane Kromm, 'Anger's Marks: Expressions of Sin, Temperament and Passion,' Netherlands Yearbook for History of Art / Nederlands Kunsthistorisch Jaarboek 6o, no. 1 (2010): 35-51 (discussion of Brouwer at 45-47).

63 Leonardo da Vinci, Treatise on Painting: Codex Urbinas Latinus 1270, trans. A. Philip McMahon (Princeton: Princeton University Press, 1956), 150-51, 156; Leonardo da Vinci, A Treatise on Painting, trans. John Francis Rigauld (London: Nichols, 1835), 94. 
Le Brun gave lectures, one of which was about the way that the philosophical painter should go about representing the passions of the soul. The lecture was delivered at the Royal Academy of Painting in 1668 and, in its published from, became the bible of expression for artists in Europe. Like Leonardo, Le Brun wanted to apply scientific principles - in his case borrowed from the philosopher René Descartes's theory of the passions - to the art of painting. It is to Charles Le Brun that we can trace back the modern project of matching individual emotion words to discrete, static, detached faces. ${ }^{64}$

For Le Brun, the aim of the painter was to show the 'movements of the heart' and the 'passions of the soul' through the faces of their figures. The eyebrows were all-important. In mild and gentle passions like wonder and love, the eyebrows moved upwards. In the wild and cruel passions, the eyebrows sloped downwards, towards the beating heart. Colère, the French term usually used for the sin of ira, and often translated as 'anger' today, came into the wild and cruel category. Le Brun gave a description both of the passion and its expression. He described colère as a mixture of pain and courage in which an injured soul withdraws into itself but also rouses itself to vengeance. This all showed in the face in an appropriately complicated way. There were enflamed eyes, grinding teeth, and hair standing on end, along with foaming at the mouth and the alternate raising and lowering of the contracted eyebrows. Also original to Le Brun, as far as I can discover, is the idea that in colère the mouth should be closed in the middle while the lips part in both corners, to reveal a 'cruel and disdainful grin' (figure 3 shows an eighteenth-century rendition of this). Le Brun, of course, produced visual images too, showing how to produce his renditions of the facial geometry of the passions, including not only 'la Colère' but also stronger, distinct feelings, including hatred, jealousy, despair and madness. ${ }^{65}$

There are three points to note about Le Brun's lecture and the associated faces of ire, rage and resentment it promoted. First, as I have already suggested, this was an innovation that marks the beginning of a tradition seeking to match faces with emotion words. Secondly, however, this is a far cry from the basic emotion of 'anger' of Ekman and his colleagues in the twentieth and

64 Jennifer Montagu, The Expression of the Passions: The Origin and Influence of Charles Le Brun's Conférence sur l'expression générale et particulière (New Haven: Yale University Press, 1994); Colin Jones, The Smile Revolution in Eighteenth Century Paris (Oxford: Oxford University Press, 2014); Lucy Hartley, Physiognomy and the Meaning of Expression in Nineteenth-Century Culture (Cambridge: Cambridge University Press, 2001); Stephanie Ross, 'Painting the Passions: Charles LeBrun's Conférence sur l'expression,' Journal of the History of Ideas 45, no. 1 (1984): 25-47.

65 Quotations are taken from the translations of the text included in Montagu, The Expression of the Passions, 126-28. 


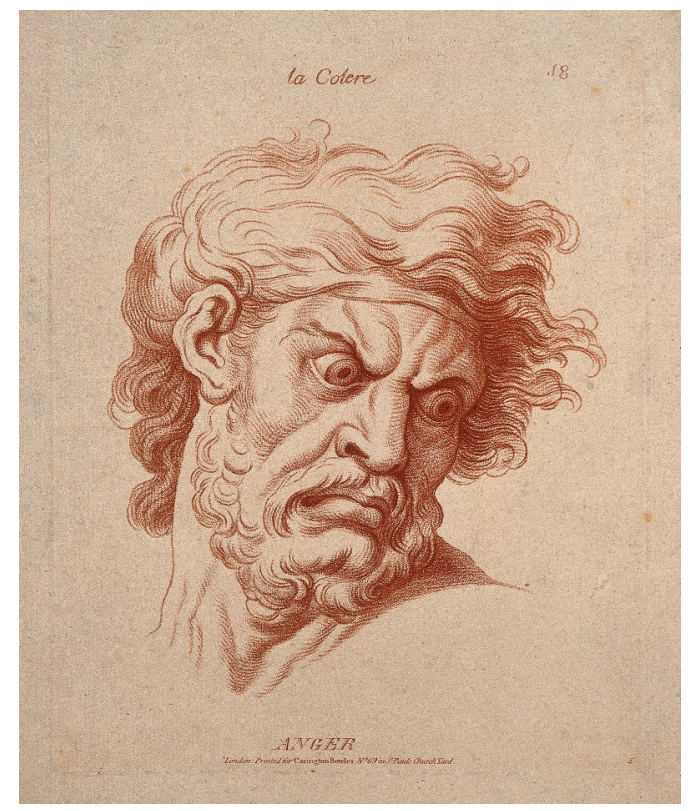

FIGURE 3

The face of a bearded man expressing anger. Etching in the crayon manner by W. Hebert, c.1770, after Charles Le Brun. Credit: Wellcome Collection. CC BY

twenty-first centuries. For Le Brun there are several distinct ire-like passions, all of which differ in definition, intensity and expression from modern 'anger'. Thirdly, from the point of view of the history of the body and its representations, it is crucial to note that, for all its philosophical precision at the time, from a later historical perspective, Le Brun's face of colère seems a physical impossibility. The lips need to meet firmly in the middle but open at both the lower corners, which are turned down in a kind of scowl, while the eyebrows should be knitted in a frown while also somehow lifting to show wide-open, bulbous eyes. Le Brun seems to have allowed his devotion to his theory to override his commitment to naturalism, which may also be true when it comes to the strangely unnatural facial poses struck by actors that are the stock-in-trade of modern-day basic emotion experiments. Nonetheless the Le Brun colère face had a long and influential history and the Scottish neurologist and theorist of expression, Charles Bell, produced a very similar configuration in his depiction of 'rage' two centuries later, even though the theory behind the face was different, with an emphasis on animal behaviour, respiration and the flaring of the nostrils. ${ }^{66}$

66 For Bell's accounts of anger and rage, see Charles Bell, The Anatomy and Philosophy of Expression as Connected with the Fine Arts, 3rd ed. (London: Murray, 1844), 94-95, 120-22, 175-77, 188-89; for wider discussions of Bell's contributions to the history of expression, 
Bell's writings were a key reference point for Charles Darwin during the decades of gestation of his pioneering 1872 book on The Expression of the Emotions in Man and Animals. Darwin took from Bell the idea that actions such as baring the teeth or flaring the nostrils came to be associated with animal passions by their usefulness in carrying out related actions such as charging at, or biting, an enemy. ${ }^{67}$ This idea of ancestral animal rage was at the heart of Darwin's account of human hatred and indignation. As he put it in the introduction to his book:

With mankind some expressions, such as the bristling of the hair under the influence of extreme terror, or the uncovering of the teeth under that of furious rage, can hardly be understood, except on the belief that man once existed in a much lower and animal-like condition. ${ }^{68}$

Darwin took a particular interest in the ability, which he interpreted as an expression of defiance, to raise the lip on just one side to reveal a canine tooth. Darwin thought that this curious lip curl (of the kind that later became Elvis Presley's trademark) revealed humanity's animal ancestry. Additionally, Darwin, who believed there was a hierarchy of human races, with white Europeans at the top, speculated that 'this animal-like expression may be more common with savages than with civilized races', although he had no evidence that it was. ${ }^{69}$

The only illustration in Darwin's chapter on hatred and anger (figure 4) shows a woman (not identified in the text, but in fact Mary Rejlander, wife of the photographer Oscar Rejlander, who provided many of the ground-breaking

see Hartley, Physiognomy, ch. 2; Philip Shaw, Suffering and Sentiment in Romantic Military Art (Farnham: Ashgate, 2013), 184-207; Ludmilla Jordanova, 'The Art and Science of Seeing in Medicine: Physiognomy 1780-1820,' in Medicine and the Five Senses, ed. William Bynum and Roy Porter (Cambridge: Cambridge University Press, 1993), 122-33; L. S. Jacyna, 'Bell, Sir Charles (1774-1842), Oxford Dictionary of National Biography, online edition, 3 January 20o8; Dixon, From Passions to Emotions, 168-75, 180-85; Dixon, Weeping Britannia, 130-33.

67 For a fuller discussion of Darwin's theory of expression and its sources in earlier theories, see Dixon, From Passions to Emotions, 159-79; Dixon, Weeping Britannia, 185-98; Paul White, 'Darwin Wept: Science and the Sentimental Subject,' Journal of Victorian Culture 16, no. 2 (2011): 195-213; Paul White, 'Darwin's Emotions: The Scientific Self and the Sentiment of Objectivity', Isis 10o, no. 4 (2009): 811-26; Gregory Radick, 'Darwin's Puzzling Expression,' Comptes rendus biologies 333, no. 2 (2010): 181-87; Tiffany Watt Smith, On Flinching: Theatricality and Scientific Looking from Darwin to Shell Shock (Oxford: Oxford University Press, 2014).

68 Darwin, Expression of the Emotions, 12.

69 Darwin, Expression of the Emotions, 239, 249-53. 


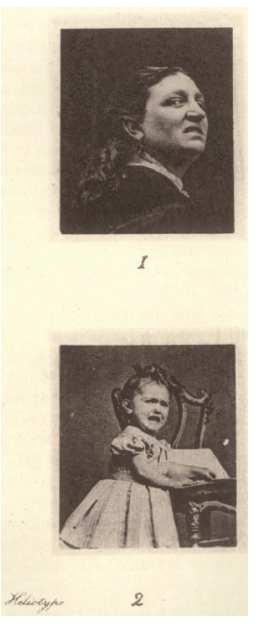

FIGURE 4

Plate IV from Charles Darwin's The Expression of the Emotions in Man and Animals, $25^{\circ}$.

photographic illustrations for the book) allegedly, but not very convincingly, performing the one-sided canine sneer of indignation, along with another photograph, of a young child crying and frowning at the same time, to illustrate the combination of anger or rage with 'misery'.70 Darwin used no image resembling either the Le Brun or Bell 'rage' face or the various different modern posed 'anger' faces used in experiments in recent decades. The body was more important than the face for Darwin, in his attempts to understand hatred and rage. He believed that the hair could stand on end in states of extreme rage, and terror, and that this human expression was a bit like a porcupine who will erect its spines and charge backwards into an enemy, or a gorilla with its erect crest of hair, its dilated nostrils, and its 'terrific yells.' ${ }^{71}$

Such embodied relics of ancestral rage, Darwin thought, became especially visible in those with weaker powers of inhibition, including children and the insane, whose animal selves were closer to the surface. As a parent, Darwin had observed how naturally children took to biting when 'in a passion': 'It seems as instinctive in them as in young crocodiles, who snap their little jaws as soon as they emerge from the egg.72 In the notes he kept about the development of his first son, Darwin observed that at the age of two years and three months, the child 'became a great adept at throwing books or sticks, \&c., at anyone who

70 Darwin, Expression of the Emotions, 231, 250; on the identification of the sneering woman as Mary Rejlander see Phillip Prodger, Darwin's Camera: Art and Photography in the Theory of Evolution (Oxford: Oxford University Press, 2009), 191-93.

71 Darwin, Expression of the Emotions, 69, 93-97, 143.

72 Darwin, Expression of the Emotions, 243. 
offended him; and so it was with some of my other sons. On the other hand, I could never see a trace of such aptitude in my infant daughters; and this makes me think that a tendency to throw objects is inherited by boys.73 Such emotional habits were, for Darwin, of no use in the modern world, but they made humanity's animal ancestry visible. In this way Darwin connected anecdotal and culturally specific ideas about emotions and gender in nineteenth-century rural Kent with his natural-historical speculations about their deep evolutionary past.

Darwin differed from modern basic emotion theorists of 'anger' in several ways. The passions and feelings Darwin described in the chapter of his book on hatred and rage did not correspond to a single emotion. The emotions there fell into at least four categories - long-standing hatred; animal rage; indignation, or 'anger'; and what Darwin called sneering or defiance. Darwin made closer comparisons with the bodily and facial configurations of other species than is usually attempted by basic emotion theorists today - the dog's snarl, the porcupine's charge, the gorilla's yell - and at the same time put less exclusive emphasis on the face. He certainly did not believe there was just one facial expression that universally conveyed a single emotion called 'anger', nor for that matter did he think that 'expressions' had evolved for the purpose of expressing emotions. ${ }^{74}$ In theory, Darwin did hope to show that forms of rage, anger and indignation were exhibited in similar ways throughout the world. However, his own commitment to accurate observation and his sense of the immense variety of the natural and human worlds meant that he was forever undermining his own attempts at universalism. The outward signs were varied and did not amount to a single manner of exhibiting anything. Under the influence of rage, defiance or indignation, a person, on Darwin's account, might go red - even purple - in the face - or conversely they might become deadly pale. Their heart might be accelerated, or disturbed, in its beating. And other aspects, such as bodily trembling, grinding of teeth, quivering nostrils, foaming at the mouth, erect hair, frantic muscular action or the revealing of a single canine tooth, happened sometimes in bouts of rage, but not always, and not for everyone.

In fact, in some respects, reading Darwin on rage is more like reading Seneca on ira than it is like reading either Le Brun on the passions or Ekman on anger. Darwin is part of a parallel but distinct line of descent of Western ideas about the body. Darwin's description of the enraged man has some striking similarities with Seneca's description of the man afflicted by ira. Darwin, as we have

73 Charles Darwin, 'A Biographical Sketch of an Infant,' Mind 2, no. 7 (1877), 285-94: 287-88.

74 Dixon, From Passions to Emotions, 159-79. 
seen, refers to human hair standing on end in rage and terror, to foaming at the mouth - especially among the insane in cases of extreme rage - and also to grinding the teeth, stamping on the ground, and even rolling around on the floor and biting, the latter among children and young apes. ${ }^{75}$ Similarly, Seneca's irate man, having lost his reason, will display a flushed red face, quivering lips, grinding teeth, hair standing on end, cracking of joints and the tendency to clap his hands and stamp on the ground. ${ }^{76}$ There is perhaps more continuity here, in the teeth, hair, feet and mouth of the enraged body, across almost two millennia of Western thought, than there is between Darwin's theory of expression and the ideas of modern basic emotion theorists, less than a century later, with their belief in a small number of evolved universal emotions with discrete and fixed singular facial expressions. And as someone whose emotions were formed in the late twentieth century, I cannot recognise my own anger in the mouth-foaming, hair-raising, knuckle-cracking, teeth-grinding passions of either Seneca or Darwin. My body has never expressed an emotion in those ways. The question then, to which I now return in the conclusion, is how best to understand both the continuities and the discontinuities in the ancestry of the components of modern 'anger'.

Writing in 2001, the American psychologist of emotion Robert Plutchik noted that 'anger', along with 'fear' and 'sadness', was one of only three emotion words to appear on every major list of purportedly basic emotions. ${ }^{77}$ As one of the most popular candidates for 'basic' status, 'anger' represents a challenging category to approach from a pluralist, constructivist standpoint. This essay has done so by marshalling historical evidence against the idea that 'anger' names any singular or universal emotion, while also arguing, constructively, that we can nonetheless shed light on the topic by excavating the separate but related histories of the words, thoughts, behaviours, feelings and bodily states which are among the leading components of modern 'anger'.

This argument - that the reification of 'anger' as a singular transhistorical emotion should be avoided - is accepted in theory by most historians of

75 Darwin, Expression of the Emotions, 241, 244-45.

76 Seneca, Anger, Mercy, Revenge, 14, 1.1.

77 Robert Plutchik, 'The Nature of Emotions: Human Emotions Have Deep Evolutionary Roots, a Fact That May Explain their Complexity and Provide Tools for Clinical Practice,' American Scientist 89, no. 4 (2001), 344-50 (349). 
emotions. In practice, however, its implications are rarely followed through. So, for instance, in their pioneering study of the history of anger in America, Carol Z. Stearns and Peter N. Stearns, while refusing to offer a definition of 'anger', and warning against reification, nonetheless described the term's meaning in singular and biologically grounded terms as 'an emotion' related to the 'fight' response. They disown the view that 'it has existed, unchanging, throughout human history', yet they set out to show how 'its meaning', in the singular, 'has evolved'. This notion that anger constitutes an 'it' already undermines the professed denial that 'it' is a singular entity. ${ }^{78}$ Similarly, the title and subtitle of a valuable collection of historical studies edited by Barbara Rosenwein in 1998 - Anger's Past: The Social Uses of An Emotion in the Middle Ages - reinforce the idea that 'anger' is the name of 'an emotion', singular, while a new book by Rosenwein, due for publication in 2020 - Anger: The Conflicted History of an Emotion - seems to risk reification in the same way. ${ }^{79}$

This essay has urged, instead, a more scrupulous avoidance of reification, pointing to the distortions involved in projecting a supposedly singular entity onto past sources. There have been multiple languages of furious feeling, concepts of vengeance and passion, and conventions of enraged facial and bodily performance, all of which form part of a complex and plural ancestry for our modern emotional lives. It is just as important when dealing with sources written in modern English as it is when interpreting texts written in other languages and periods to avoid distorting the meanings of pre-twentieth-century historical actors by interpreting their references to 'fury', 'resentment', 'disappointment', 'warmth', 'heat', 'passion' or even 'anger', as statements about 'anger', as understood in a post-196o psychological sense..$^{80}$

78 Carol Zisowitz Stearns and Peter N. Stearns, Anger: The Struggle for Emotional Control in America's History (Chicago: University of Chicago Press, 1986), 15-16.

79 Barbara H. Rosenwein, ed., Anger's Past: The Social Uses of an Emotion in the Middle Ages (Ithaca, NY: Cornell University Press, 1998); Barbara H. Rosenwein, Anger: The Conflicted History of an Emotion (New Haven: Yale University Press, 2020); advance publicity on the Yale University Press website implies that the book will treat 'anger' as the name of a singular emotion whose story can be told from Buddha to the present.

8o There are, as I read them, tendencies towards such distortion in two excellent scholarly works about anger-like emotions in eighteenth- and nineteenth-century America, namely Nicole Eustace, Passion is the Gale: Emotion, Power, and the Coming of the American Revolution (Chapel Hill, NC: Published for the Omohundro Institute of Early American History and Culture, Williamsburg, Virginia by University of North Carolina Press, 2008), esp. ch. 4; and Linda M. Grasso, The Artistry of Anger : Black and White Women's Literature in America, 1820-1860 (Chapel Hill, NC: University of North Carolina Press, 2002), 10, which refers to a singular 'anger paradigm' as the interpretive key to the various texts under consideration. A similar comment is made above about Pollock, 'Anger and the Negotiation of Relationships.' 
Because language helps to constitute, and does not merely stick labels onto, emotional experiences, changes in the words and concepts used across time and space for emotional states represent more than mere lexical plurality. Such changes reveal experiential plurality. There are multiple discontinuities that hold apart the experience of, for instance, committing the sin of ira and fearing for the eternal consequences of doing so in fifteenth-century Europe, and expressing the modern emotion of 'anger' in a way that resembles the cartoon character of that name inside the brain of the fictional Riley in the 2015 Disney Pixar movie Inside Out. The Ekman-Pixar world has no place for sins and punishments, nor for reason, virtue or conscience..$^{81}$ To experience and express modern 'anger', in the absence of those concepts, is to have a different experience from those who were gripped by ira in an earlier age and who saw it in moral scenarios rather than isolated faces. It is not to experience the same emotion but in a different, more 'modern' way. That was also the point of my analyses above setting out the differences between modern ideas of 'anger' and the ancient passions and pleasures conjured up by Homer, Aristotle and Seneca.

This pluralist position invites two potential objections. Critics of the approach advocated here might reasonably point towards continuities that do exist, for instance between Seneca and Darwin or even between Homer's narrative and some emotions in the present, and challenge the pluralist to accept that there must be shared emotional capacities underlying those continuities which mean that modern individuals, including historians of emotions, can have some insight into the emotional lives of others who lived in the past, by virtue of a shared humanity. Different scholars will have different views on this, but my own response is to agree with this imagined critic. I believe there is a shared humanity that means I can try to empathise with and understand the emotional experiences of others, even those in distant cultures and eras. It may be that there are biological and neurological affinities shared among all humans that mean they can expect to have a comparable, while by no means identical, range of emotional experiences. However, this general and somewhat undefined belief in a shared human capacity for feelings is a long way from a commitment to the idea that ancient and modern experiences are expressions of a single set of 'emotions', defined and theorised in modern terms.

Even if there are some physiologically grounded dimensions to anger-like, emotion-like experiences in all cultures, that is very different from the claim

81 Thomas Dixon, 'Inside Out and the Democracy of the Modern Mind,' The Conversation (UK edition), 28 July 2015, https://theconversation.com/inside-out-and-the-democracy -of-the-modern-mind-45202. 
that there is a universal emotion that exists across all historical periods and which is picked out successfully by the contemporary English-language psychological construct 'anger'. I can believe in a set of constraints on the range of emotional experiences available to homo sapiens by virtue of their evolved bodies, without believing in the truth of some particular theory of emotions as set out in late-twentieth-century Anglophone psychology. Additionally, there may be cultural universals that can be identified independently of questions of hard-wired physiology. For instance, it is clear that many cultures make use of images of heat, fire, eruption, boiling and explosion when describing certain hot and displeasing states. To recognise a commonality of such metaphors is not to subscribe to a theory of basic emotions. ${ }^{82}$

The second, harder, challenge to the pluralist historian of emotion is to explain how, if 'anger' does not refer to a real and discrete human emotion that has existed in all societies, historians are to select the materials for inclusion in their histories of 'anger'. This is the real import of the question posed by the title of this essay. One possible solution, and the one that has been implicitly or explicitly adopted by almost all historians of 'anger' previously, is to stipulate a definition of 'anger' in the present (even a vague one like that offered by Stearns and Stearns, who say it is related to a biological 'fight' response) and then to look for anything in past cultures and other languages that seems to resemble that definition closely enough. William V. Harris attempts something like this in his book Restraining Rage: The Ideology of Anger Control in Classical Antiquity. On the one hand, Harris argues strongly for linguistic, conceptual and experiential plurality, and tries to keep this plurality in readers' minds by referring to 'anger-like emotions' and 'angry passions' rather than to 'anger' in the singular. On the other hand, however, to justify his inclusion of a wide range of different states with various Greek and Latin names within his remit, Harris offers a stipulative definition of the core phenomenon he is interested in: 'a vigorous, temporary, emotional condition in which the subject desires the object's harm, and/or desires to attack the object with words, because of some perceived failing. 83

82 Zoltán Kövecses, 'Anger: Its Language, Conceptualization, and Physiology in the Light of Cross-Cultural Evidence,' in Language and the Cognitive Construal of the World, ed. John R. Taylor and Robert E. MacLaury (Berlin: de Gruyter, 1995), 181-196; Zoltán Kövecses, 'Cross-Cultural Experience of Anger: A Psycholinguistic Analysis,' in International Handbook of Anger, ed. Potegal, Stemmler, and Spielberger, 157-74; Gevaert, 'The Anger Is Heat Question'.

83 Harris, Restraining Rage, 40. A valuable recent article about Thomas Aquinas's views on ira and 'payback' follows a similar pattern - offering a persuasive statement of the plurality of meanings of the term 'anger' and the non-existence of any objective reality 
Like all attempts to define 'anger' in a way that can be historically generalised, Harris's quickly falls apart. Let me mention three problems. First, people - as Harris himself repeatedly points out - in both the ancient world and the present can be gripped by slow-burning anger-like states over long periods of time, such as mênis or hatred. Such passions are not necessarily either 'vigorous' or 'temporary'. Secondly, Harris's inclusion of a desire for revenge (whether physical or verbal), like Nussbaum's similar insistence, discussed above, excludes many ideas and experiences categorised as anger, fury and ire, ancient and modern, which do not include such a desire. Thirdly and finally, both Harris and Nussbaum offer definitions which fail to mention the bodily and behavioural elements - the red face, the clenched jaw, the flared nostrils, the raised voice - that many of us in a post-Darwinian and post-Jamesian world might consider pretty central to any experience we would want to label 'anger'.

So, if we cannot assume that ira, or orge, or yrre, or Zorn are the same thing as 'anger', and if we are unable to define 'anger' in a satisfactorily generalisable way, then what is left as a criterion for inclusion in our history of anger? The present essay has suggested the answer to that question by thinking of modern emotional states as complex, emergent, multi-component realities that can be subjected to an analysis combining techniques of anatomy and genealogy. In Rembrandt's painting of an anatomy lesson, the students look on as their teacher demonstrates the structure of the human body by pulling apart its bones, nerves, organs and sinews. ${ }^{84}$ I think of historians of emotions doing something similar, treating emotional states not as self-evident unities but as composites made up in intricate ways from words, categories, narratives, metaphors, images, moral beliefs, religious attitudes, visual representations, bodily responses, behaviours, public performances, subjective experiences, feelings and testimonies. Each of these separate components itself has a history. And those components can come together in different formations at different times to constitute different affective categories, types and patterns.

A striking example of this phenomenon - the coming together of separate historical lineages of words, faces and ideas to form a temporary, distinctive

corresponding to the term, before succumbing nonetheless to the temptation to stipulate a definition of a common core of characteristics shared by all states that can rightly be referred to as 'anger': 'a basic, common feature of such experiences is a felt impulse, in the wake of a perceived wrongful injury, to rise up against the source of the injury or an obstacle that it has created, and compel it to behave in a way that strikes the person as desirable': Jan Rippentrop Schnell and Diana Fritz Cates, 'Rethinking Anger as a Desire for Payback: A Modified Thomistic View,' Religions 10, no. 11 (2019), 1-31 (1, 9).

84 Rembrandt, The Anatomy Lesson of Dr Nicolaes Tulp (1632), oil painting on canvas, Mauritshuis Museum, The Hague, the Netherlands. 
emotional constellation - can be found in Imke Rajamani's research. She shows how popular Indian movies of the 1970s created a new virtuous and vengeful role for male leads, labelled by Indian journalists with the English-language phrase 'angry young man', and identified by their red eyes and beads of sweat, set against a backdrop of fiery volcanoes, weapons and violence. ${ }^{85}$ The English phrase 'angry young man' was imported into the Hindi language alongside conventions from the ancient rasa theory to create a novel emotional type - something that was distinct from but related to emotional states available either to Anglophone Westerners or to Indians of earlier centuries. The rasa tradition offers a distinctively Indian theory of art, feeling, and expression. The rasa is the emotional tone, flavour or essence that is created by a work of art. ${ }^{86}$ The raudra rasa is an atmosphere of demonic fury and violence, and is generally considered the closest rasa to the emotional world of 'anger'. The bodily and facial states that are used to perform in the mood of raudra include shouting, sweating, cracking your knuckles, biting your lips, shedding tears and having red eyes. Judging by modern Western conventions, however, the raudra face does not look like an 'anger' face, but more closely resembles that associated by Western psychologists with surprise or disgust. ${ }^{87}$ In the 'angry young man', then, English words with a particular history combined with ancient visual traditions of performance quite separate from the categories of modern psychology, all within the particular cultural politics of India in the 1970s and 1980s. The result was an emotional type, with a partially shared cultural and bodily history to Western 'anger', but one with its own distinctive coherence.

Whether in the ancient state of mênis, the medieval sin of ira, the 'angry young man' of Indian cinema or the basic emotions of Inside Out, we can recognise cultural formations that have resemblances to each other, partially share their ancestries, and are connected by demonstrable links of cultural transmission and translation, without resorting to invoking the existence of some single thing called 'anger'. The history of 'anger', understood in this anatomical

85 Imke Rajamani, 'Pictures, Emotions, Conceptual Change: Anger in Popular Hindi Cinema,' Contributions to the History of Concepts 7, no. 2 (2012): 52-77.

86 Sheldon Pollock, ed., A Rasa Reader: Classical Indian Aesthetics (New York: Columbia University Press, 2016), Preface, esp. xvi on the relationship between rasa theory and Western 'emotions'.

87 Michelle Voss Roberts, Tastes of the Divine: Hindu and Christian Theologies of Emotion (New York: Fordham University Press, 2014), 138-40; Jan Plamper, The History of Emotions: An Introduction (Oxford: Oxford University Press, 2015), 109-13; Pollock, A Rasa Reader, 333n12; Susan L. Schwartz, Rasa: Performing the Divine in India (New York: Columbia University Press, 2004), 66. 
and genealogical way, is, as I intimated at the outset, both presentist and historicist. The criterion for inclusion is ancestral connection with our presentday discourses, definitions and experiences of 'anger', and so to that extent this is a history of the present, but one undertaken on the most historicist possible principles. ${ }^{88}$ Once identified as cultural ancestors, the ideas and images, moral attitudes and theological questions, forms of arousal and facial contortions, can be reconstructed on the kind of richly contextualised basis proposed by exponents of anthropologically inflected forms of historical scholarship such as microhistory. 89

The history of emotions gives us access to alternative ways of naming and framing human feelings and so can liberate us from the hold of dominant psychological and psychiatric categories in the present. This realisation equips us to interrogate prophets of 'anger' today. It allows as to ask them which aspects of the ancestry of modern 'anger' they wish to revive, whether that might be the desire for revenge on the one hand, or a moral rejection of the irate on the other. The modern theory of basic emotions can make it seem as though the 'anger' which commentators would have us believe is all around us, and which some say is an inherited desire to slaughter our enemies, is a universal bequest from our evolutionary ancestry, singular, natural and inevitable. It is none of these things, because there is no 'it'. However, it is possible to make this plea for pluralism without drowning in relativism, and to be entirely historicist about the ancestry of 'anger' while still living critically and constructively in the present.

\section{Acknowledgements}

The research for this essay was made possible through Wellcome Trust Collaborative Award no. 108727/Z/15/Z, 'Living with Feeling: Emotional Health in History, Philosophy, and Experience'. I am grateful to colleagues too numerous to list, over several years, who have commented on research papers and

88 I discussed this with Rob Boddice, who has written widely about these issues, in 'Rob Boddice, A History of Feelings, Q\&A,' The History of Emotions Blog, 1 October 2019, https:// emotionsblog.history.qmul.ac.uk/2019/10/rob-boddice-a-history-of-feelings-qa.

89 Robert Darnton, The Great Cat Massacre and Other Episodes in French Cultural History (New York: Basic Books, 1999); Carlo Ginzburg, The Cheese and the Worms: The Cosmos of a Sixteenth-Century Miller, paperback ed. (Baltimore: Johns Hopkins University Press, 1992); Carlo Ginzburg, trans. John Tedeschi and Anne C. Tedeschi, 'Microhistory: Two or Three Things That I Know about It,' Critical Inquiry 20, no. 1 (1993): 10-35. 
talks I have given on this subject in Britain, Europe, and Australia, for their perceptive feedback, questions, and suggestions. I have benefited from a dynamic and collegial institutional context at Queen Mary thanks to my colleagues on the 'Living with Feeling' project and in the School of History. I am especially grateful to Sarah Chaney, Tiffany Watt Smith, and Emily Butterworth who read and commented on earlier drafts of this essay, and to the anonymous reviewers for EHCS and the journal's editors for their guidance and suggestions in clarifying the ideas in this essay. 